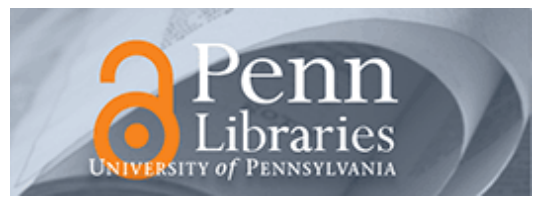

University of Pennsylvania

ScholarlyCommons

Management Papers

Wharton Faculty Research

2008

\title{
Three's a Crowd? Understanding Triadic Employment \\ Relationships
}

Matthew Bidwell

University of Pennsylvania

Isabel Fernandez-Mateo

Follow this and additional works at: https://repository.upenn.edu/mgmt_papers

Part of the Business Administration, Management, and Operations Commons, Business and Corporate Communications Commons, Human Resources Management Commons, Labor Relations Commons, Management Sciences and Quantitative Methods Commons, and the Organizational Behavior and Theory Commons

\section{Recommended Citation (OVERRIDE)}

Bidwell, M. \& Fernandez-Mateo, I. (2008). Three's a Crowd? Understanding Triadic Employment Relationships. In Cappelli, P. (Ed.), Employment Relationships: New Models of White Collar Work, 142-178. Cambridge University Press.

This paper is posted at ScholarlyCommons. https://repository.upenn.edu/mgmt_papers/350

For more information, please contact repository@pobox.upenn.edu. 


\title{
Three's a Crowd? Understanding Triadic Employment Relationships
}

\author{
Abstract \\ There are many facets to the typical employment relationship. At its very simplest, employment involves \\ the exchange of labor for compensation. Nevertheless, employment relationships also involve control of \\ the worker by the firm, the acquisition of skills through experience and training, learning about each \\ others' qualities and intentions, and career progression as the worker moves from role to role within the \\ organization. In addition, employment usually imposes a variety of specific legal obligations on both \\ employer and employee. Traditionally, these obligations have been combined into a single relationship \\ between worker and firm.

\section{Disciplines} \\ Business Administration, Management, and Operations | Business and Corporate Communications | \\ Human Resources Management | Labor Relations | Management Sciences and Quantitative Methods | \\ Organizational Behavior and Theory
}




\section{Three's a crowd? Understanding triadic employment relationships}

MATTHEW BIDWELL AND ISABEL

FERNANDEZ-MATEO

\section{Introduction}

There are many facets to the typical employment relationship. At its very simplest, employment involves the exchange of labor for compensation. Nevertheless, employment relationships also involve control of the worker by the firm, the acquisition of skills through experience and training, learning about each others' qualities and intentions, and career progression as the worker moves from role to role within the organization. In addition, employment usually imposes a variety of specific legal obligations on both employer and employee. Traditionally, these obligations have been combined into a single relationship between worker and firm.

In recent years, however, we have seen the growth of "triadic" employment arrangements, in which important characteristics of employment are divided among workers' relationships with two firms: a "client" and an "intermediary." The intermediary generally acts as the legal employer of the worker, but the actual work is performed at a client site. Consider, for example, employment relationships for temporary agency workers. Legally, the worker is employed by the agency, ${ }^{1}$ which also provides the worker with compensation and any benefits. Career progression for the worker often results from the worker being assigned by the agency to roles in different clients. The worker's relationship with the client also has clear elements of an employment tie, however: the worker provides labor to the client at its site; the worker often also accepts substantial control by the client over his or her work. We cannot therefore understand how the worker is employed without examining both these ties.

Many other industries beyond temporary help agencies display "triadic" features. The outsourcing of services often involves individuals

1 We use the terms "agency," "intermediary," and "staffing firm” interchangeably throughout the chapter. 
working closely with a client firm and accepting control by them, while also being employed by an outsourcing vendor. In professional services, the roles of client and employer can become blurred as close relationships with clients become a central determinant of workers' career success. In order to understand the nature of employment fully in many settings, therefore, we need to look beyond traditional employer-worker dyads and examine the nexus of relationships that surround the employment ties in which workers are embedded. This chapter focuses on triadic employment relationships that involve a labor market intermediary, a worker, and a client firm.

We argue that the distinctive feature of triadic arrangements is that they cannot be understood by examining each tie in isolation; the different ties within the triad interact with each other. For all three participants - workers, intermediaries, and clients - relationships with one of these actors become a tool for managing their relationship with the other. As a result, outcomes such as wages, task assignment, and employment security can be understood only by referring to all three relationships. In order to develop a nuanced understanding of these arrangements, we draw on insights from the sociological literature on exchange theory (Cook and Emerson, 1978; Blau, 1964) and our qualitative analysis of three different studies of triadic employment among high-skilled workers. We discuss the implications of this framework for our conceptualization of new employment relationships more generally.

\section{Defining triadic employment arrangements}

In triadic employment relationships, the traditional functions of the employer are shared between the client company and the intermediary. In the archetypal case of temporary help services, the agency is the legal employer of record. It manages the screening, hiring, wage setting, discontinuation of employment, and payment of benefits to the worker. It is also responsible for the administrative aspects associated with maintaining employees on payroll, such as retaining taxes, paying wages, etc.

The client company usually has no contractual relationship with the worker. It is closely involved in many aspects of the employment relationship, however. Often the client will participate in the screening and hiring processes, making final decisions on the candidates proposed 
to them by the agency. In addition, the client will usually be responsible for all functions relating to the work, including task allocation, supervision of the workers, and even provision of specific training when required. The work frequently takes place at the client's site.

The details of triadic employment can vary along a number of related dimensions, however, even within the same industry settings. First, there is widespread variation in the stability of the worker's relationship with the intermediary. Some workers will expect to build long careers with the same intermediary. Other workers' relationships with the intermediary will last only as long as their assignment with a particular client. Second, there is variation in whether the intermediary is expected to play a role in managing the workers. Some intermediaries sell their services to clients on the basis of their expert project management. Other intermediaries provide only the workers. Third, there is variation in whether workers are expected to bring intermediary-specific knowledge to the client, or whether they are being hired solely for general skills.

These variations make it difficult to construct a clear definition of triadic employment relationships for the purposes of collecting statistics on these arrangements. As a result, detailed statistics on the prevalence of triadic employment relationships are hard to come by. In general, there seems to be a consensus that the importance of mediated work arrangements in general - and agency employment in particular has increased considerably during the last decade (see Davidov, 2004). According to a recent comparative survey, work through temporary help agencies grew between two- and fivefold during the 1990s (Storrie, 2002, cited in Davidov, 2004). Estimates from various sources suggest that this type of employment could account for as much as 2.7 percent of the labor force in France, around 2 percent in the United Kingdom and United States, and some 0.7 percent in Germany (Storrie, 2002). Precise and comparable statistics on this issue are scarce, however.

In part, this absence of good data reflects the difficulty of defining what exactly constitutes an employment relationship. In the United States, for example, rather than having a single clear definition, courts often rely on the answers to a ten- or even twenty-question test to decide who a worker's formal employer is (Muhl, 2002). Furthermore, the legal status of workers involved in triadic employment relationships varies across countries (see Davidov, 2004).

The US Bureau of Labor Statistics has made some attempt to count the number of individuals in alternative employment arrangements 
through a biennial supplemental survey of workers, the Contingent and Alternative Employment Arrangements Supplement to the Current Population Survey (CPS). According to the 2005 survey, around 0.9 percent of workers are employed by temporary help agencies, and a further 0.6 percent are employed by firms that contract out their services to other companies. These numbers have remained fairly stable over the ten years that the survey has been running. Given the difficulties in cleanly defining these employment arrangements, however, there is good reason to believe that these figures present a low estimate of triadic employment in the US labor force.

Figures collected from industry-level employment data paint a very different picture of the extent and growth of triadic employment. According to figures provided by the BLS (see table 5.1), temporary help firms employed 2.4 million individuals in 2006, representing around 1.8 percent of the labor force. Professional employer organizations, which provide long-term staffing services for businesses, employed a further 700,000. Large numbers of workers were also employed in computer systems design, management and technical consulting services and business support services, all of which often involve employees working very closely with clients over long periods of time such that the client takes on some characteristics of the employer.

Perhaps most strikingly, the BLS figures reveal rapid growth in the industries that make widespread use of triadic employment relationships. Temporary help services grew by 121 percent between 1990 and 2006. Computer systems design services grew by 202 percent. Professional employer organizations, which serve as employers of record for entire company workforces, grew by an impressive 621 percent. Hence, while triadic employment relationships may still be the exception rather than the norm, they are present in a significant and rapidly growing portion of the US labor market.

It is most likely that this growth in triadic employment relationships reflects a growing trend towards more arm's-length, market-mediated ties between firms and workers (Cappelli, 1999; Osterman, 1999). In response to increased competition in product markets, greater pressures from shareholders, and reduced government regulation, firms have sought to increase their flexibility by limiting their obligations to workers (Pfeffer and Baron, 1988; Cappelli, 1995). Much of the growth of intermediaries can be explained by the need to manage functions that employers have abandoned. We review the many 
Table 5.1 Employment growth in industries with triadic employment arrangements, 1990-2006 (thousands of employees)

\begin{tabular}{lccc}
\hline Industry & January 2006 & January 1990 & Percentage change \\
\hline $\begin{array}{l}\text { Employment placement } \\
\quad \text { agencies }\end{array}$ & 289 & 209 & 38 \\
$\begin{array}{l}\text { Temporary help services } \\
\begin{array}{l}\text { Professional employer } \\
\text { organizations }\end{array}\end{array}$ & 2429 & 1097 & 121 \\
$\begin{array}{l}\text { Computer systems design } \\
\text { and related services }\end{array}$ & 1222.6 & 405.2 & 202 \\
$\begin{array}{l}\text { Management and } \\
\text { technical consulting } \\
\text { services }\end{array}$ & 856.3 & 310.6 & 176 \\
$\begin{array}{l}\text { Business support services } \\
\text { Total non-farm } \\
\text { employment }\end{array}$ & 752.7 & 497 & 51 \\
\hline
\end{tabular}

Source: Bureau of Labor Statistics.

functions that intermediaries provide in the next section. Some growth is also likely to be a response to employment law. A variety of different laws within the United States create obligations between employers and employees (Muhl, 2002). Firms must pay a number of employment taxes and withhold taxes from their employees' pay. In addition, the US tax code requires employers to offer benefits to their employees in order for them to receive favorable tax treatment. As a result, employers can be liable to pay benefits to workers who the courts find to be their employees, as happened in the Microsoft vs. Vizcaino case (Monthly Labor Review, 1998). Finally, anti-discrimination legislation and other legal innovations have seriously eroded the "employment at will" doctrine within the United States, making the termination of employment a much more difficult prospect for firms (Autor, 2003). Stephen Barley and Gideon Kunda (2004) argue that client firms often hire workers though an intermediary to shield themselves from these legal obligations. ${ }^{2}$

2 Obviously, when intermediaries function as legal employers of these contractors they are the ones shouldering the employment risks. In these cases, however, it is common for the client to pay a premium to hire agency temps, so the "costs" are ultimately born by the clients as well. Nonetheless, the intermediaries are usually 
Merely defining workers as independent contractors does not guarantee that courts will not judge a client firm to be their legal employers, but when workers are hired through an intermediary many lawyers believe that client firms are much less likely to be defined as employers.

\section{Toward an understanding of triadic employment arrangements}

The increasing importance of alternative employment relationships has motivated a number of studies that examine the different features of these non-standard work arrangements. Many of these studies have focused on understanding when and why firms choose to use external employees such as temporary help agency workers and outsourced personnel (e.g. Abraham, 1990; Davis-Blake and Uzzi, 1993; Abraham and Taylor, 1996; Houseman, 2001; Gramm and Schnell, 2001; Houseman, Kalleberg, and Erickcek, 2003). Many of these studies find that a key reason for firms to use external workers is to achieve greater "numerical flexibility" to meet seasonal or uncertain demand, or to fill positions left vacant due to sickness or vacations. Temporary employment also allows firms to screen potential full-time hires (see Autor, 2001), as well as to bypass some internal administrative controls on recruiting, such as hiring freezes, rigid pay scales, unionization, or the requirement to pay benefits (Houseman, 2001).

A second stream of research has focused on the consequences of externalized employment for workers and firms. These studies suggest that contingent work, compared to regular employment, is associated with more of the characteristics of "bad jobs," such as low pay and lack of benefits (Kalleberg, Reskin, and Hudson, 2000), that contingent workers have less organizational commitment than regular employees (Van Dyne and Ang, 1998; Ang and Slaughter, 2001), and that the use of external workers can lead regular employees to have poorer relationships with peers and supervisors and increase their intentions to quit (Broschak and Davis-Blake, 2006).

Recent research has also begun to explore the actions and role of intermediaries in these markets, such as IT staffing firms (Barley and Kunda, 2004) and executive search firms (Finlay and Coverdill, 2000). This research emphasizes the variety of functions that intermediaries

better able to bear these costs, as they usually offer lower benefits as well as offering short-term employment to all their employees. 
perform in the labor market, such as matching workers to firms, negotiating pay (Barley and Kunda, 2004), and screening workers for clients (Autor, 2001). Studies have also examined the broader impacts of these intermediaries in helping certain groups of workers to advance their careers (Bielby and Bielby, 1999) and shaping how client firms are able to achieve greater employment flexibility (Davis-Blake and Broschak, 2000).

These studies provide detailed insights into the causes and consequences of these new employment arrangements. They also provide some indication of how various aspects of employment relationships are "taken over" by employment intermediaries. None of them fully explores the consequences of the triadic nature of these settings, however. Instead, most studies tend to examine one set of relationships at a time: the relationship between worker and client; the relationship between worker and agency; or the relationship between agency and client. The distinctive feature of triadic employment relationships, however, is that all three ties are intimately involved in shaping how workers are employed. As a consequence, focusing on any one relationship within the triad can deny some of the most important dynamics that shape that relationship.

This point was made long ago by sociological studies on the structure of interactions among actors. The German sociologist Georg Simmel (see Wolff, 1950) was the first to point out, in an article published in 1902 , that the underlying social structure of triadic interactions is fundamentally different from that of dyadic ones. He argued that, as one additional actor is involved in a transaction, the quality and the dynamics of how the parties interact with each other change. In particular, ties bound by a third party give each actor less autonomy, less power, and less independence in relating to the other members of the triad (Krackhardt, 1999). The study of social networks has drawn heavily on this insight to suggest that the way that any single relationship behaves depends on the broader network of ties in which it is embedded (Burt, 1992; Gargiulo, 1993). That is, the terms of the exchange depend not only on the characteristics of the specific relation that is the focus of the exchange but also on the ties that each partner has to the other actors (Baron and Hannan, 1994).

One way to conceptualize the distinctive dynamics of triadic employment arrangements is to examine how the actors use the different ties as a resource for strategic action. Any relationship can be understood 
as the outcome of two parties seeking to minimize the costs and maximize the benefits that they can obtain. In triadic relationships, each of the actors has an additional resource to use in its interactions with a second party: its ties to the third party. Hence, workers might leverage their ties with the intermediary in order to improve the terms of their relationship with the client; they might also leverage their ties with the client in bargaining with the intermediary. The other ties in the triad similarly provide resources to intermediaries and clients in dealing with workers. This idea is consistent with social exchange theory (Cook and Emerson, 1978; Blau, 1964), which argues that the actors involved in a given exchange can draw on their actual or potential ties to other actors as an additional resource. In the remainder of this chapter we present the results of qualitative research that seeks to identify and to understand these interactions among the different relationships within employment triads. We discuss how actors might, at different times, seek to strengthen relationships (which leads to what we call "reinforcement") or to weaken them (which we call "balancing"). ${ }^{3}$

\section{Data and methods}

Our data comes from three complementary field studies of triadic ties in high-skill contract labor markets. The figures combine depth and breadth, as they include extensive observations from a number of diverse settings as well as intensive interviews and quantitative data collection within each setting. We integrate two in-depth studies of particular institutional actors - a staffing agency and a client firm - with a broad study of all three participants in the market. The fieldwork was implemented in the market for high-skill information technology contractors, broadly defined. The staffing firm ("the agency") we studied is a global company headquartered in the United States that specializes in placing "creative" IT professionals. We also analyzed the use of contractors within the IT department of a large US financial services firm ("the

3 These correspond closely to the concept of network polarity within social exchange theory (Cook and Whitmeyer, 1992), which classifies ties as positively or negatively connected, depending on how they interact. Ties are positively connected when the magnitude of one exchange in which an actor is involved produces or implies an increase in a second exchange. Conversely, ties are negatively connected when an increase in the frequency or magnitude of one exchange produces a decrease in the second exchange (Emerson, 1972). 
bank"). These two in-depth studies are complemented by a third set of cross-firm interviews with agencies, consultants, and clients across a range of different settings that focused on understanding the range of different employment relationships in the IT consulting industry. See table 5.2 for a summary of our data collection and methods.

\section{Study 1: the agency}

The agency is a large, global staffing firm that specializes in placing workers with creative, technical, and Web-based skills. The firm is headquartered in a major US city and has subsidiaries in more than ten countries - although our study focuses on the United States alone.

The agency operates by matching workers to projects in client firms. It holds a database with extensive information both on contractors looking for projects and on companies looking for workers. ${ }^{4}$ The matching begins with the agency receiving an order from a client, and searching its database to find someone that fits the assignment description. This results in a simultaneous matching process whereby candidates are offered potential assignments and clients typically are presented with a selection of résumés. At the same time, price negotiations begin between the agency and the client company. Contractors are paid a percentage of the billing rate the agency receives from the client. Generally the workers do not get to know how much the agency is billing the client for its services, and they rarely have a chance to negotiate wages. Moreover, as part of their general agreement to work together, the agency explicitly advises both client and contractor not to discuss billing rates and wages (Barley and Kunda, 2004, provide a detailed discussion of this issue).

Once the three parties have reached an agreement, the contractor starts working at the client firm's site, ${ }^{5}$ usually alongside the company's

${ }^{4}$ We use the terms "contractors" and "workers" interchangeably throughout the chapter.

5 The majority of triadic employment relationships that we analyzed at the agency consisted of individuals working as contractors at the client company's site. The study of the agency did not focus on arrangements in which contractors perform a project for the client firm but work off-site in their own office or studio (see Kunda, Barley, and Evans, 2002, for some examples of this type of relationship). We interviewed a few such independent contractors, who usually charge a lump sum for their work, but most of our analysis is limited to the far more common cases in which contractors work alongside the client firm's regular employees. 
Table 5.2 Summary of three studies of triadic relationships

\begin{tabular}{|c|c|c|c|}
\hline & The agency & The bank & The market for IT consulting \\
\hline Study setting & $\begin{array}{l}\text { US office of global staffing } \\
\text { agency }\end{array}$ & $\begin{array}{l}\text { IT department of large US } \\
\text { financial services firm }\end{array}$ & $\begin{array}{l}\text { Variety of clients, consultants } \\
\text { and agencies in IT service } \\
\text { market }\end{array}$ \\
\hline Types of workers & $\begin{array}{l}\text { IT-related graphical design } \\
\text { services }\end{array}$ & $\begin{array}{l}\text { IT professionals (systems and } \\
\text { software developers) }\end{array}$ & $\begin{array}{l}\text { IT professionals (systems and } \\
\text { software developers) }\end{array}$ \\
\hline $\begin{array}{l}\text { Types of agency } \\
\text { services }\end{array}$ & $\begin{array}{l}\text { Short-term staffing of workers to } \\
\text { clients }\end{array}$ & $\begin{array}{l}\text { Staffing of workers to clients; } \\
\text { management of development } \\
\text { projects }\end{array}$ & $\begin{array}{l}\text { Short-term staffing of workers to } \\
\text { clients; management of } \\
\text { development projects }\end{array}$ \\
\hline $\begin{array}{l}\text { Research } \\
\text { methods }\end{array}$ & $\begin{array}{l}\text { Periodic field observation; } \\
\text { interviews; analysis of agency } \\
\text { records }\end{array}$ & $\begin{array}{l}\text { Periodic field observation; } \\
\text { interviews; surveys; analysis of } \\
\text { contracts }\end{array}$ & Interviews \\
\hline Quantitative data & $\begin{array}{l}\text { Job histories of } 251 \text { individuals } \\
\text { placed by the agency in } 457 \\
\text { clients ( } 1480 \text { projects) over } \\
5 \text { years }\end{array}$ & $\begin{array}{l}\text { Survey data on the staffing and } \\
\text { management of } 57 \text { software } \\
\text { development projects }\end{array}$ & \\
\hline Informants & $\begin{array}{l}\text { Placement agents, contractors, } \\
\text { industry experts }\end{array}$ & $\begin{array}{l}\text { Senior managers, sourcing } \\
\text { managers, project managers, } \\
\text { developers }\end{array}$ & $\begin{array}{l}\text { Convenience and snowball } \\
\text { sample of clients, consultants, } \\
\text { agency managers, industry } \\
\text { experts }\end{array}$ \\
\hline $\begin{array}{l}\text { Number of } \\
\text { interviews }\end{array}$ & 45 & 62 (plus 57 in-person surveys) & 36 \\
\hline
\end{tabular}


regular employees. The staffing firm is the "employer of record," which means that the worker is formally employed by the intermediary and has no contractual relationship with the client. The client firm pays a fee to the agency - usually per hour of work - for the contractor's services, and the agency in turn pays the worker - also hourly. When the worker receives benefits, these are provided by the staffing firm, not by the client. Formally, the staffing firm is also in charge of supervising the contractor's work and solving any problems that may arise in the relationship. In practice, however, project managers usually deal directly with contractors on a day-to-day basis. ${ }^{6}$ Most projects have an established duration usually a few days or months - but sometimes they are open-ended or are regularly renewed. As a norm, contractors do not receive a salary when they are not assigned to a project by the staffing firm, and often workers are registered with several intermediaries at the same time.

Our data collection at the agency focused particularly on understanding the consequences of triadic employment relationships from the perspective of the worker, but it also aimed to study the internal functioning of labor market intermediaries. We studied the agency over the course of fifteen months. During this period we carried out repeat interviews with the agency's placement agents and, around three times a week, we observed their activities for three to four hours a day. As well as observing the agency, we implemented a series of interviews with individuals who had been affiliated with the agency at some point in their careers, and others who had worked as contractors in this sector but never joined this particular agency. ${ }^{7}$ This involved interviews with forty-five individuals, some of whom were interviewed several times. The sample includes thirty-seven contractors (twenty-six of whom had been affiliated with the agency at some point, although not necessarily at the time of the interview), four placement agents at the agency, and two industry experts. ${ }^{8}$

${ }^{6}$ By actively managing the external worker, the client runs the risk of being found to be the legal employer of the worker. The demands of smoothly coordinating the work, however, generally require that clients become closely involved in external workers' day-to-day activities.

7 The former were contacted through the agency's managers, while the latter were members of several professional and industry associations in the local area of the agency's headquarters.

8 Besides this qualitative data, we also collected a wealth of quantitative information on contractors' job histories. We assembled a data set from a variety of sources 


\section{Study 2: the bank}

The bank is a large financial services institution based in the United States. Our study focused on its IT department, which employed over 10,000 people and was responsible for developing and maintaining all the systems that the bank used to conduct its business. At the time of the study, around one-third of the developers at the bank were external workers employed under a triadic employment relationship. These external workers fell into three broad categories. T\&Ms (time and materials consultants) were hired through staffing firms, but were managed exclusively by managers at the bank. Integrators were employees of consulting firms, which took a more direct role in managing projects, contributing significant institutional expertise. These workers were most likely to be engaged by the bank for very highly skilled work, often involving system design and interaction with the business. Finally, offshore workers were employed by foreign organizations and were usually physically located overseas, commonly in India, to carry out basic, lower-skilled development work. We studied how the bank managed these three types of external workers through interviews with sixty-two individuals at all levels of the organization, and a structured survey of fifty-seven project managers that examined how they managed internal and external workers.

\section{Study 3: organizational forms adopted by intermediaries}

The third study was a broad exploration of the relationships of all three participants in the market for IT consultants. Where our studies of the bank and the agency focused on gaining in-depth insights into particular organizational actors, this study sought to understand the variety of different kinds of organizations and relationships present in the market for IT consulting. In particular, we were interested in understanding the variety of organizational forms adopted by the intermediaries, and their implications for the relationship with clients and workers. We

provided by the agency (paper résumés, client information, demographic data, project characteristics, prices, etc.), as well as public information on size and industry classification of clients (see Bidwell and Fernandez-Mateo, 2006, for a full description of our quantitative data). We have comprehensive information on 251 individuals who were placed in 457 different companies between 1998 and 2002, making a total of 1,480 assignments. 
interviewed thirty-six informants, including eight consultants, twelve managers of intermediaries, twelve clients and three industry analysts drawn from a convenience sample of clients, consultants, and intermediaries, based on personal contacts and referrals. These informants were associated with a wide variety of different kinds of intermediaries, from those firms that focused purely on staffing to organizations that also sought to provide project management and other institutional expertise to their clients. They were mainly located in the north-east of the United States. We also attended three industry conferences for IT staffing firms.

\section{Data collection and analysis}

Our qualitative data collection process consisted of both fieldwork observations and the implementation of semi-structured interviews. The interviews ranged from thirty minutes to two hours, with the average being one hour. We asked open-ended questions, which varied depending on the type of interviewee - worker, client, placement agent, etc. - but in all cases we paid special attention to the relationships among the three parties.

We analyzed these interviews by carefully reading and re-reading our transcripts and field notes, and by using a computer-assisted qualitative analysis tool (Atlas.ti). We used an iterative data analysis process (as described in Glaser and Strauss, 1967, and Miles and Huberman, 1994) in order to build a simple inductive framework for analyzing the different interactions among the participants.

\section{Results: the impact of triadic interactions on employment outcomes}

In analyzing our interviews, we find that there were many instances of our informants - unprompted - discussing how one tie would shape the way another tie was formed and managed. These interactions varied along three important dimensions: (1) who was involved in managing the relationships; (2) the kind of outcomes that were affected, including pay, task allocation, and job security; and (3) whether the actors were attempting to reinforce their relationships or balance one relationship with another. We focus on the latter dimension in order to organize the discussion of our findings, since we are interested in the dynamic aspect of how triadic ties interact with each other. 


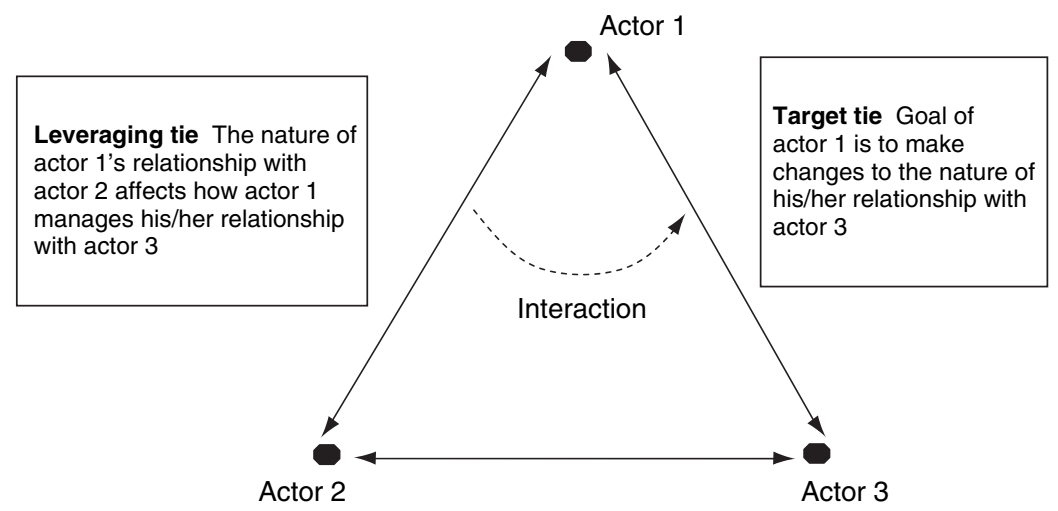

Figure 5.1 Defining interactions within a triad

\section{Reinforcement}

The most common pattern of interactions within the triad involved using one tie to strengthen, or "reinforce," another. Quite often actors benefited from strong ties to other actors. In these cases they tried to use this strong tie with one of the parties in order to forge a stronger tie with the other - a process of reinforcement. Such behavior would result in all three ties within the triad becoming stronger, a situation that social exchange theorists describe as "positive polarity" among ties (Cook and Whitmeyer, 1992). In this context, we use the term "strengthening" (and the reverse: "weakening") to mean mostly four things: creating a new tie; increasing the tangible and intangible resource flows that are exchanged through a tie (i.e. information, material resources, reputation); increasing the control that the actor has over the terms of the relationship; or increasing the probability of future transactions. Although each of these outcomes is somewhat different, we felt them to be sufficiently similar that we could collapse them into a single dimension. ${ }^{9}$

9 To some extent, all these outcomes signal an increase (or decrease) in the tangible and intangible resources that flow through a tie. Establishing a new tie increases the resource flow from zero to some other amount, while increasing the probability of future exchange contributes to a growing flow of resources between the actors at some point in the future. Control could be conceptualized in part as the increased ability of an actor in the relationship to dictate the terms of the exchange, which can be thought of as a consequence of this actor having some resource that the other party values (Emerson, 1976). This conceptualization of relationships as exchange networks closely resembles that of social exchange theorists (Cook and Emerson, 1978; Blau, 1964). 


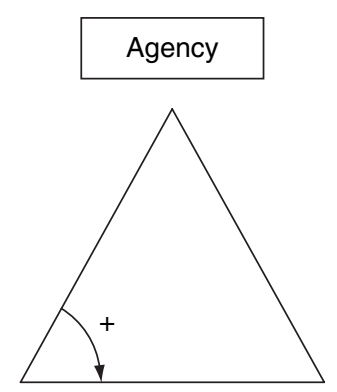

\section{Client}

Worker

Client-agency, client-worker

Figure 5.2 Bridging and buffering

Reinforcing behavior was pervasive throughout these triadic systems. We have found examples of it between each of the pairs of ties. We also observe how such reinforcement behaviors contributed to shape a variety of employment terms, including pay, task assignment, and job security. We present examples of these processes below.

\section{Bridging and buffering: reinforcement between client-agency and client-worker ties}

All accounts of triadic labor markets begin with the idea that clients leverage their tie with an agency to build a tie with a worker. When clients lack the networks that will help them to recruit workers for shortterm assignments they turn instead to agencies, the wider networks of which allow them to propose workers for the position (e.g. Barley and Kunda, 2004). This is the most obvious function of an intermediary: working as a broker by matching workers to firms. Not surprisingly, such brokerage behavior was pervasive throughout the markets we looked at. In most cases, clients would use agencies to find potential contractors, but then do the final selection themselves. In some cases, when the client had a strong enough relationship with an agency, they might instead rely on that agency to perform all the screening for them. For example, managers at the agency we studied mentioned during informal conversations that some clients trusted their judgment on 
candidates so much that they did not get involved in the selection of candidates at all.

The influence of the agency on the relationships between client and worker extended well beyond its most obvious brokerage function of matching workers to jobs, however. In fact, both workers and clients used agencies to buffer themselves against a variety of risks associated with their ongoing relationship. Agencies facilitated a relationship between client and worker that would otherwise be too risky.

At the most basic level, clients use agencies to buffer them against legal risks. A concern for many clients was that they could be legally classified as the employer of a consultant, and therefore held responsible for withholding taxes from and paying benefits to the worker (see Barley and Kunda, 2004, for a detailed explanation of this issue). As a consequence, clients might insist that workers who approached them be employed by an external agency, even though that agency would have played no role in finding the worker. For example, one consultant told us:

I started working for [the client] as an intern. Then they wanted to bring me on as an employee, but they couldn't get an employee req [requisition form approved]. Instead they called up [the agency] and told them to hire me.

Agencies also protect clients from risks related to workers by guaranteeing their performance. In some cases clients would sign a contract with the agency for the specific work to be performed. If for some reason the worker fails to perform, its relationship with the agency ensures that the work will be completed. In explaining why he preferred to deal with larger agencies that would take responsibility for the work rather than independent contractors, one client said that

larger firms do have extra resources to call on. If you have a small company or individual and they get pneumonia for two weeks, then you are in real trouble. With a larger company, they have back-up project management to make sure that work does get delivered rapidly and on time.

In both these examples, the presence and nature of the agency-client relationship was critical to the formation of a client-worker relationship. Moreover, clients also used agencies to manage their relationship with the workers on an ongoing basis. Perhaps the most extreme example of this was the way that clients used their relationship with agencies to manage wage reductions. As the literature on internal labor 

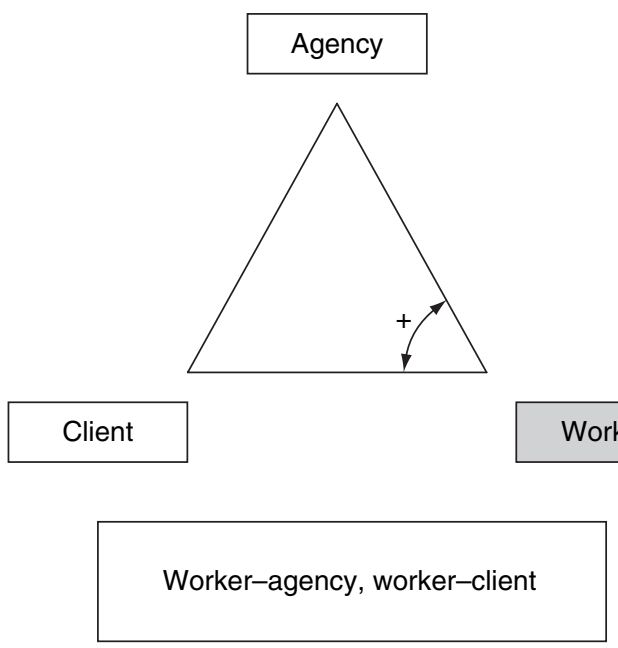

Figure 5.3 Brokering the broker

markets makes clear, it is extremely unusual for firms to reduce the wages of regular employees (Doeringer and Piore, 1971; Baker, Gibbs, and Holmstrom, 1994). During the period 2000-2002, however, demand for IT workers fell sharply in many areas, leading clients to attempt to cut expenditure by reducing consultants' pay. The fact that consultants were formally employed by third-party agencies facilitated these attempts; by positioning the rate cuts as inter-firm transactions, clients were able to reduce the damage to their relationships with the workers. As one client described:

In fall 2001 we had our first line of reductions. We left it to the vendors as to how to manage it. We just told them: "We want a 10 to 20 percent reduction in your overall bill rate - you figure out how to do it." We told them that 10 percent was the absolute minimum reduction we wanted, and if they got as high as 20 percent they would make us very happy.

\section{Brokering the broker: reinforcement between worker-agency and worker-client ties}

Just as clients use agencies for more than simply finding a qualified worker, so workers use agencies for more than simply finding work. Indeed, we find that there were a number of situations in which workers chose to build a relationship through an agency despite having an existing relationship with the client. As we have seen, 
clients often like to involve agencies in their relationships because of the guarantee this provides about the quality of the work. At times, therefore, workers need to involve an agency in order to maintain and strengthen an existing tie with a client. For example, one manager at an agency explained how workers can act as brokers, introducing an agency to a client in order to shore up their own relationship with the client:

We had a key number two or number three player on a piece of work, where they contracted to us for the first time, as a try-out, if you will. They [the two contract employees] did well. They had access to another client. Tenuous access. But access. It was then much easier to walk in with a portfolio of [the agency's] projects, rather than for John to come back and say I have a ragtag team of folks, and I can assemble a team. Instead he would introduce me. And that's all I had as well. Except I had a body of work, a reference list, and my references were all CFOs [chief financial officers]. So when you pick up a phone, and you get a call in to a CFO, who can then tell you: "I've hired these people three or four times."

Alternatively, workers might choose to work through an agency because of the increased security from ties to a firm that would find them work and provide them with secure pay. When clients wanted to hire these workers, they would have to do so through that agency, even when they had a pre-existing link with them.

Once they started working with the client, workers could exploit their ties with the agency they were using in order to strengthen their relationship with the client. In particular, the agency could be an important source of feedback for the worker about how the job was progressing. For example, one worker described how

I e-mail them [the agency] when I need something, or they e-mail me when they need something, I always ask them to give me [the client] feedback, and they are always like, you know, they love you, everything is great, you know.

We find that there were very tangible ways in which this reinforcement behavior benefited workers. In a separate analysis of wage and billing rates at the agency we studied, we show that workers with longstanding relationships with the agency were able to command higher bill rates from the client, and higher wages overall (Bidwell and Fernandez-Mateo, 2006). Longer relationships with workers allowed the agency to learn about their strengths and weaknesses, and therefore provide a better fit with client needs. This better alignment improved 


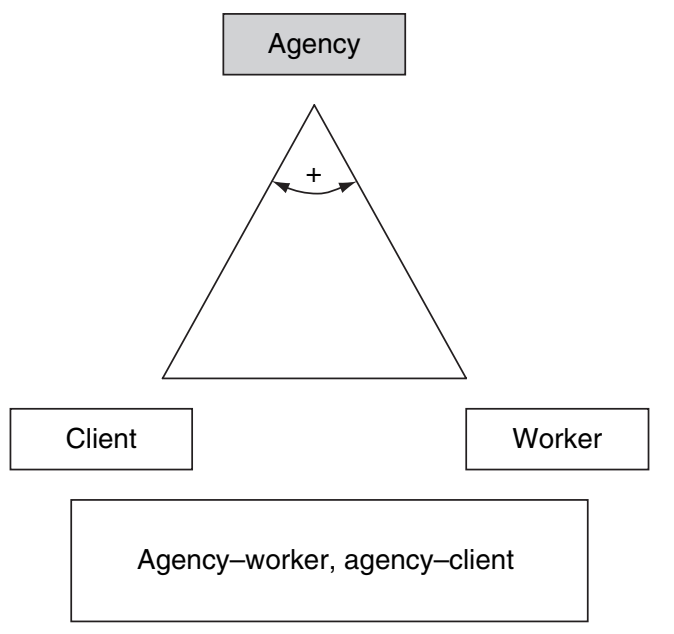

Figure 5.4 A means to an end

the quality of the worker-client relationships, and therefore the amount that clients were willing to pay for a worker.

Reinforcement also occurred when workers leveraged their ties to clients to improve their relationships with an agency. The most obvious way to achieve this was to ensure that agencies received feedback from the clients when jobs were going well, so that the agencies would be more likely to choose them on future assignments. As one consultant said:

I mean, you make sure that the people you are working for they like what you do and they call up [the agency] and they say: "Oh boy, did he do a good job" you know, stuff like that.

\section{A means to an end: reinforcement between agency-worker and agency-client ties}

While accounts of triadic employment relationships have tended to focus on how the participants - especially intermediaries - achieve the right client-worker match, the three actors are at the same time actively managing their other relationships. Success for agencies depends largely on how they manage their relationships with their clients. When the agency-worker tie is a critical resource in managing client relationships, these ties become reinforcing.

For example, agencies would use workers to build relationships with clients by deciding whom to assign to a particular client. These staffing 
decisions are not just a case of finding the best fit between worker and job; the nature of the relationship with the client shapes which workers are selected by the agency to work there. For example, if an agency was trying to build a reputation with a new client it would send a worker whom it knew well and trusted to do a good job, in order to make a good impression on the client. As one placement agent told us about new clients:

I might place the good one there in order to give them a great first impression of [the agency] so they keep doing business with us.

Alternatively, following a failed placement, an agency would try to ensure the next person that it sent was somebody with whom it had an established relationship, and could be trusted to do a good job. As one such worker told us:

You can always try to send them a good talent to mend things up. I do a lot of that, like I've been sent in to a lot of difficult clients, or I have been sent in to a lot of situations when they want to win a client over.

Close relationships with workers could help agencies to woo clients in other ways. In particular, workers can be a valuable source of information about clients for agencies, helping placement agents to do more deals. This is another reason for agencies to assign workers with whom they have close relationships to key clients. As one placement agent explained:

We are not in the client, so we need someone to help me understand their structure, the organizational chart. We use for that the talent we place there as well, in order to get a better understanding of the company and see what might be the next step for us to expand.

Such dynamics had important consequences for how ties between clients and workers were built. What kind of job they were matched to was not just a function of workers' skills and the requirements of the job; the nature of agencies' relationships with particular clients also influenced how workers were assigned to jobs.

The need for agencies to build strong client relationships also shaped their ties with workers. To the extent that close relationships with contractors helped agencies to win business, they were more likely to build strong ties to these workers. The need to reinforce client relationships could therefore induce agencies to put workers on a salary. Many 
of the agencies had arm's-length relationships with their workers, paying them only when they were able to find a job for them. Such an arrangement reduced the agencies' costs, as they did not have to pay the workers for "bench time" when they had not been placed; it also had its disadvantages, however. Without the expectation of a long-term relationship with an agency, workers had less incentive to represent that agency in the best light, and were more likely to seek work elsewhere. As the client's relationship with that agency became more dependent on the skills and performance of the workers it supplied, the agency would be more likely to employ them on a full-time basis. Doing this would also "bind" the workers to some extent, as they would no longer be able to have arrangements with other agencies if they were receiving a full-time salary.

We find that this strengthening of the agency-worker relationship was particularly evident when agencies presented themselves to clients as managing the overall delivery of the services. In these circumstances, agencies wanted to be able to present key workers as possessing the expertise necessary for the project. As it became necessary to draw on this expertise with increasing frequency, it also became necessary to employ these workers full-time. Similarly, when agencies were responsible for the delivery of projects, they might feel that the risks involved in arm's-length relationships with their staff were too great. As one manager in a high-end consulting firm told us:

People don't feel comfortable going into battle with a lot of mercenaries. When the going gets tough, they are not going to stick around. Similarly, we don't tend to do easy projects. If they were easy, then the clients would do them themselves. We don't want people to run away when the project gets tough, and that is the concern with contractors.

To the extent that workers could directly affect the client relationship, they were more likely to be made employees of an agency. As another manager at the same integrator firm put it:

Where we use contractors most is where we have the most control of them. This is where [the agency] has been given a job to build a complete system to deliver to the client, and is building it on our own premises. In these cases, if a contractor doesn't shape up then it is pretty easy for us to take corrective action. 
I feel much more nervous about using contractors at the client site. Then they get introduced to the client, get to know people, and we are much more exposed. All of our people have been rigorously screened, but not the contractors. Having them there starts to muddy the water.

Finally, the need to build client relationships could lead the agencies not only to build long-term relationships with the workers but also to train and certify them in new technologies. As the manager of another integrator explained to us:

Almost everybody is certified. [The agency] will pay for our staff's certification ... It is an additional feature in your sales. Many of the certification levels in Java and so on are actually pretty rigorous. They give a sense to clients that the people really do know their stuff. The clients don't have to worry about it.

Just as the client-agency tie could provide a motive for agencies to strengthen their ties with their workers, it could also provide a resource for such strengthening. A simple way that agencies achieved this was by providing workers with as much information as possible about the client. This information helped the worker to prepare for the assignment and eased the transition into the new job. As the assignment progressed, regular updates about what was happening at the client company could be useful to the workers. The provision of such information was, therefore, an important service that agencies could offer to the workers, and one that would differentiate them from other agencies (and potentially win over good contract workers). It was also something that contractors often commented on:

When I worked with [a specific agent], she was amazing, she went to check out everything, she would tell me what they were like, she would tell me what the place is like. She would tell me, you know, how to get there, if there was parking ... she was very amenable to all the things that would affect me - she was amazing.

On occasion, agencies might also leverage their relationships with clients in more substantial ways to help manage their ties with workers. Given that the client ultimately shaped the conditions of work, agents needed to work with these clients to manage how they improved rewards for workers. An agency's relationship with a client could therefore be used to improve things for the worker. There were examples of such behavior at the bank we studied, where the close relationship between 
the client and the offshore vendors meant that the bank would be relatively responsive in helping the vendors to manage their relationships with the workers. One of the bank's managers gave us an example of this:

Now that I have worked with these people [outsourcing vendors] repeatedly, I can guess who the people on the other side will be. I can cut them slack in how they do the work. If they want to fly someone over to do something, I'll let them, even if it is not strictly needed for the project, because it might help to reward and develop the individual. I am happy to do this sort of thing as long as the work comes in under budget.

\section{Balancing}

Although strong relationships often benefited the actors within the triad, this was not always the case. Sometimes, strong ties could expose actors to significant costs and risks. For example, relationships with workers might create legal liabilities for clients. This would mostly be due to the risk that contractors - even those hired through agencies might be classified as employees in the case of a legal dispute. In such a case, agencies would be liable for any benefits awarded to these workers (see Monthly Labor Review, 1998). Similarly, the mere existence of a relationship with an intermediary implies that workers and agencies have to pay a price for its services. When these risks and costs become high, actors might seek to use their other relationships to minimize the costs and risks, thereby effectively weakening relationships. We describe these effects as "balancing behavior" (Emerson, 1962; Gargiulo, 1993), in which a stronger relationship with one of the actors actually leads to a weaker relationship with the other one. Once again, such behavior was widespread among all three actors, and had consequences for a variety of employment outcomes.

\section{Disintermediation: balancing between client-worker and agency-worker ties}

Many accounts of triadic labor markets paint the intermediary as the tertius gaudens, who gains rents from bringing two previously separated parties together (see Wolff, 1950; Burt, 1992; Marsden, 1982). A clear corollary of such a framing is that, once introduced, it is in the interest of the other two parties to remove the broker from the triad. Disintermediating the broker in this way allows the other two parties to 


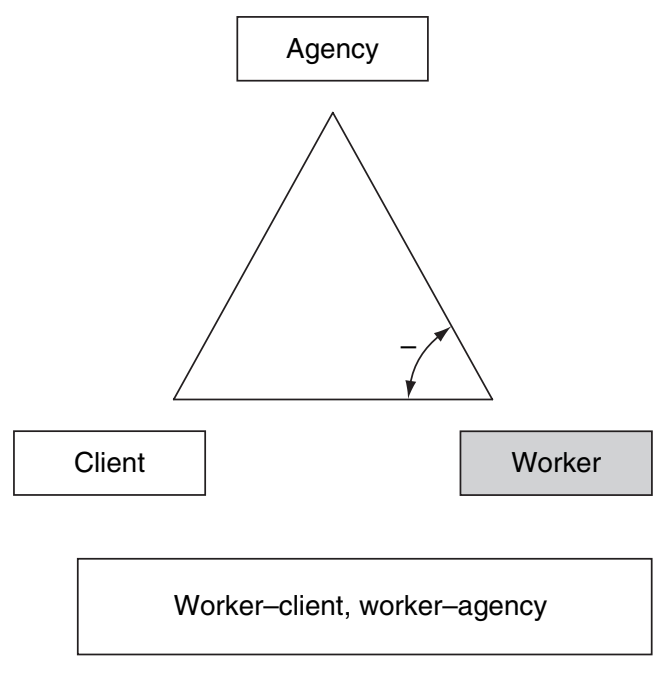

Figure 5.5 Disintermediation

share the rents previously appropriated by the broker - in this case the agency fee.

Attempts at such disintermediation were an important feature of triadic labor markets. In most cases, agencies would write contracts with clients that forbade the client from hiring the worker directly without compensating the agency, or would introduce a non-compete clause that committed the worker and the client to not contracting directly among themselves for a period of time - usually one year - after the intermediary had matched them. In fact, such clauses and provisions are generally part of the business model used by most labor market intermediaries (see also Barley and Kunda, 2004). Furthermore, cases of disintermediation were taken very seriously by agencies, which might even sue workers or clients who broke non-compete agreements. For example, during the course of our research at the agency we studied, one of the agents learned that a contractor had signed a direct agreement with a client the agency had assigned them to a few weeks earlier. Pandemonium ensued. Placement agents shouted at each other, made frantic calls to the agency's lawyers, and threatened client and worker with legal action unless some kind of monetary agreement was reached. Needless to say, ties with both client and contractor were immediately severed.

Even where non-compete clauses are respected by all participants, such legal devices cannot always prevent disintermediation. For 
example, such contracts are ineffective when individuals from the client firm moved companies. As one contractor told us:

When a CFO would leave [their current job], having established a personal relationship with one or two players, they understood that the contract house was merely making a large margin, so they were more than happy to deal with me or others directly, because it lowered their cost basis, and we were known entities, so you could walk into an environment and bring a new $\mathrm{CFO}$ to this environment up to speed within two weeks' time.

We also saw many instances of partial disintermediation - that is, attempts to minimize agencies' role in the relationship without removing them altogether. An example of this is when workers attempt to negotiate pay and conditions directly with their clients rather than going through agencies. In some cases, such partial disintermediation represents a clear attempt by the two parties to reduce the agencies' rents from the transaction. ${ }^{10}$ In other cases, though, partial disintermediation reflects the fact that as the clients and the workers get to know each other they become more likely to resolve issues directly between themselves in a timelier and more efficient manner. These two faces of disintermediation mean that agencies have complex reactions to the phenomenon. For example, one agency manager told us:

In my firm, more than 90 percent of the consultants are salaried, benefited and have tenure. Because of this, I frown on them going to the client directly to discuss their rate. In previous years, though, they would come back to me and say: "My rate is below the market." This should not be the client's problem. Instead, the agency should continually be in touch with its consultants to ensure that any problems are rapidly resolved.

By contrast, we came across cases in which partial disintermediation directly benefited the agency. According to one contractor:

10 In fact, our quantitative work suggests that workers who are able to establish stronger relationships with clients extract higher rents from the agency (Bidwell and Fernandez-Mateo, 2006). When workers have performed several engagements with the client in the past, retaining their services becomes important for the agency in maintaining its tie with the client. As a result, the agency would pass significantly more of its billings on to the workers. 
When I worked for this financial company for almost one year I thought, well, I am becoming very valuable for them, and I think we can up the pay rate, so I spoke to my boss at the client directly, which I guess technically you are not supposed to do, and I said to her: "I really think I should get paid more by the hour," and she agreed. Then I went back to [the placement agent], and said: "I've spoken to the client and we are going to bill more."

Balancing behavior could also happen when workers used the intermediary to distance themselves from their clients. It was usually in the interest of the workers to strengthen their relationship with the clients; after all, this was the source of their pay. Nonetheless, when workers became too dependent on their clients, the agencies could prove a useful resource for reducing this dependence. Perhaps the most obvious example of this behavior was in how agencies protected workers from the risk of non-payment on behalf of the clients. Even when clients did not pay for the work, the contractors would be paid by the agencies something that would not have happened had the workers been hired directly by the clients as independent contractors.

Workers could also use the agencies to buffer themselves against their clients in other ways. For example, when workers had longerterm relationships with agencies, they might choose to have the agency intercede for them to resolve problems that they encountered with the client company. As one contractor told us:

Well, the people that I see every day, that are my direct managers, I count them as my boss; I'd say they are the people I talk to if I have any [problems] at work, but if I have any question about the way I'm being treated or something like that, I would probably go to [the agency].

In the words of another:

The way you have to do as a contractor for an agency - if you have a problem you have to talk with the agency, call your agent and tell him this is what happens and you are going to have to ... because I am not gonna react.

For particularly valuable workers, the intermediary might even go so far as to provide the worker with the rewards that the client was refusing. One contractor told us: 
I managed to negotiate a week off ... [T] hey want to renew the contract, they want to do the same thing for a different client ... I have been able to negotiate that, consequently they were able to negotiate a lower rate with my agent ... "Oh, she is asking for a week off" ... so they are asking for less money ... I get the same rate, I don't pay the difference - I know, because the client told me.

\section{Bargaining and distancing: balancing between client-worker and client-agency ties}

Just as the worker could be active in attempting to disintermediate an agency, so could the client. Many of the examples of client-led disintermediation attempts that we came across revolved around information. As Barley and Kunda (2004) note, information about billing rates tends to be jealously guarded by the agencies, on the basis that it helps them to maintain higher margins. In response, many clients attempt to force agencies to practice "open book" pricing, so that all the parties know what the margin is. Such pressures tend to drive down agencies' rent, and may also lead to a deterioration in service in the market. One agency manager told us:

Recently there has been a lot of pressure on margins and clients pushing for greater visibility of their margins. To be honest, we hate this. We are trying to run a business, and this pressure for transparency makes that difficult. We have a $\$ 70$ million operation in the US, and we are trying to deliver a quality service. The pressure for full disclosure diminishes what they do by just focusing on the labor rate ... People like IBM who pushed for full disclosure said that they do it because they want to make sure that the maximum dollar goes to labor. I am not embarrassed to say that we have shareholders, and so we need to make sure that we are making money for them.

Such partial disintermediation tactics (pushed by the clients) became particularly important when agencies were attempting to present what they did as a service, rather than purely the provision of individuals. By focusing on the individuals that an agency was providing (and thereby downplaying the role of the client-agency relationship in providing the service), clients were able to reduce that agency's rent significantly. One client described the process of negotiating with a high-end consulting firm as follows: 


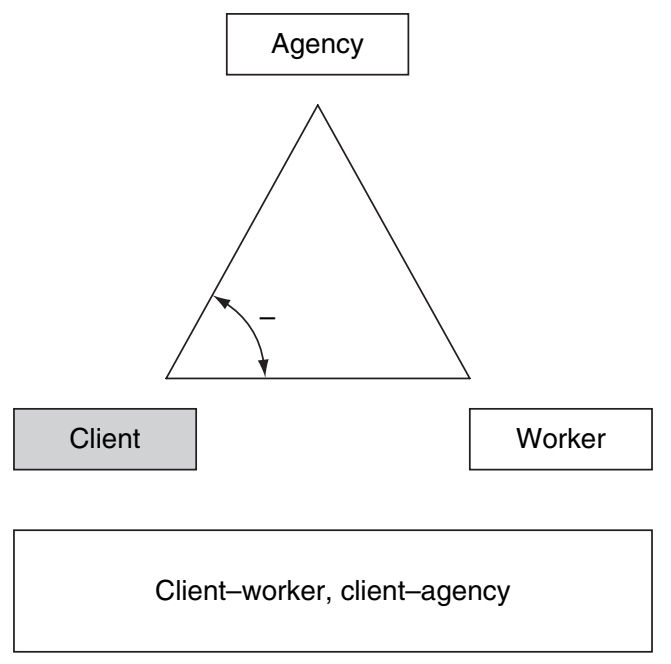

Figure 5.6 Bargaining and distancing

Some of the push back that [the client manager] used was that what looked like very different people had very similar pay levels. Even the terminology is different across these people [for different firms] so how do you do an apples to apples comparison of the individuals and roles and peg a price on them? You need to come up with a matrix of titles in this company versus those in the other. We kind of did this, but not as formally as we might have ... However, [the client manager] really saved a lot of money on these projects, pushing back on these issues.

While the threat of disintermediation was usually damaging to an agency's interests, sometimes the agency needed to accept it in order to conduct the transaction. Some clients might require the option of direct hiring in order to do business with an agency. For example, when the bank we studied used offshore personnel via a vendor to manage some of its key systems, it became highly dependent on the knowledge of those external workers. This dependence made the bank very vulnerable to "hold-up" behavior by the vendor during contract renegotiations, as the knowledge about the vendors' personnel was effectively irreplaceable. In order to manage this problem, the bank made it a condition of its use of offshore vendors that it had the right to interview and employ the vendors' employees should the relationship between client and vendor be terminated. 
It was not always in clients' interest to engage in such partial disintermediation of agencies. Indeed, the reason that clients brought agencies in originally was to balance their relationship with workers. Accordingly, clients would often use their relationships with agencies in order to distance themselves from the workers. For example, when clients were dissatisfied with particular workers, they would often leave the job of releasing the individuals involved to the relevant agencies. There were also many situations in which the client would want to weaken the tie to workers within the context of an ongoing relationship.

The main reason why clients would want to weaken their own ties with workers was to simplify the process of managing the work. When agencies took greater responsbility for managing what the workers did the resources needed by the clients to manage their projects were reduced. Clients achieved this through more detailed contracts with agencies, making the agencies responsible for delivery of the services. This meant that clients could rely on the agencies to do the management. A senior manager at the bank we studied outlined this logic to us as he explained how he was trying to train his subordinates to deal with offshore vendors:

Anecdotal evidence is no longer acceptable to me in talking about problems with the offshore vendors. My questions would ... be, first, should you even be talking to this person? Or is someone else named as the point of contact in the contract? How does this relate to the contract? How has it actually affected your performance on the contract? Are their English skills even relevant to your evaluation of the vendor? [...] We want to focus on "These are the deliverables. Are they acceptable, on time and on price?" Ultimately, you can't control the other issues, and that's supposed to be one of the advantages of outsourcing - you shouldn't be worrying about who they hire.

Building a strong relationship with an agency was therefore critical to the client's ability to reduce its own contact with the workers. There was a clear tension, however, between, on the one hand, the client's desire to minimize the effort devoted to managing the workers and, on the other, its goal of limiting agency margins. Reducing the status of the agency involved to that of a broker enabled the client to lower margins. Limiting the burden of managing the workers required the client to bring the agency back into the relationship as an active participant, however. 


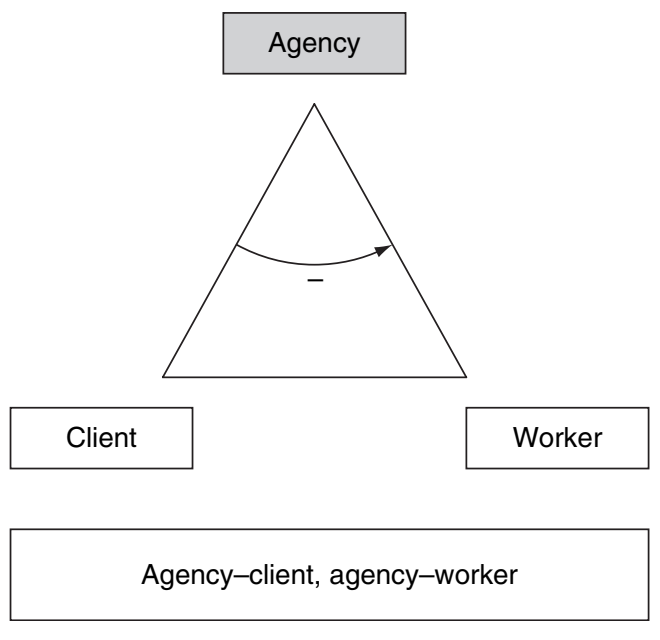

Figure 5.7 Taking themselves out

\section{Taking themselves out: balancing between agency-client and agency-worker ties ${ }^{11}$}

As we have seen, disintermediation was generally beneficial to clients and workers, but damaging to agencies. Nevertheless, we did come across instances in which agencies chose to disintermediate themselves - something that it would have been difficult to anticipate from most of the literature on brokerage and intermediation. While intermediating between clients and workers brought returns in the form of fees, it also carried costs. Among the most serious of these costs was the prospect that poor performance on the part of workers would damage agencies' relationships with their clients. In a few cases, agencies perceived these risks to be very high, yet were not able to remove the worker from the client. In those situations, agencies would encourage their clients to hire the worker directly. An agency manager described just such a situation to us:

11 Isabel Fernandez-Mateo (2007) has analyzed a related kind of balancing behavior on the part of agencies, which focuses on price setting. In particular, she finds that intermediaries offer discounts to clients with which they have stronger relationships (those of strategic importance). Instead of this reducing their margins, however, agencies are able to transfer these discounts to workers, who as a result get lower pay rates when assigned to these firms. In a sense, the agencies are using their relationship with the workers to alleviate the price constraint imposed by their ties to powerful clients. 
We have had our people do terrible things, like stealing, but had the client not want to do anything about it. This puts me in a difficult position, as ultimately we are liable for what our people do. In one case, we told the client that if they wanted to keep the consultant they would have to convert them, as we were not prepared to deal with the liability of having that person on our payroll. The client then went ahead and converted the person.

\section{Discussion and conclusions}

Many new employment relationships are triadic in nature, as opposed to traditional dyadic - employer-employee - relationships. Instead of consisting of a tie between a worker and a firm, these relationships involve three actors in the exchange of employment services: a company, a worker, and an intermediary of some sort (see also Kunda, Barley, and Evans, 2002). As a consequence, understanding new employment arrangements requires the examination of a distinctive feature of triadic relationships: the fact that all three ties within the triad interact with each other. We have used concepts borrowed from social exchange theory (Cook and Emerson, 1978; Blau, 1964) to begin to explore this phenomenon, by arguing that not only do the terms of exchange between two given actors depend on the characteristics of the tie between them, but they are also determined by their ties to other actors. In particular, the "third relationship" can be an additional resource - and sometimes a constraint - that the parties draw on when interacting with the focal actor.

\section{Workers}

Our findings on how relationships within a triad interact with each other in high-skilled contract labor markets have important practical implications for workers, intermediaries and clients. Workers involved in mediated arrangements need to understand the existing tie between the client and the intermediary in order to appreciate how their relationship with both actors will evolve. In particular, we have described several ways in which client-agency relationships can significantly affect workers. For example, the strength of the intermediary's tie with the worker - including whether the intermediary employs the worker full-time - depends on whether the intermediary's tie with the client relies on claims of expertise and the provision of guaranteed performance. 
Similarly, workers will be more likely to be "managed" by the intermediary rather than the client when the client-agency relationship is stronger. Client-agency relationships also influence job assignment, as agencies' decisions about which workers to allocate to which projects depend in part on how the agencies seek to develop their relationships with different clients. For example, agencies will appoint their most trustworthy contractors to valued current or potential clients, either to protect their relationship with them or to strengthen it for the future. As a result of these processes, workers involved in triadic employment arrangements need to understand how to make full use of their relationship with each party in the triad, and be aware that ties are not just an end in themselves but also a powerful means of shaping other relationships.

\section{Intermediaries and clients}

Our findings also have implications for intermediaries and clients. For the former, they are a reminder of the central importance of their relationships with workers in shaping how they deal with clients. For the latter, they illustrate that ties with labor market intermediaries need to become an integral part of their human resources strategy. When using the services of an intermediary, a company is necessarily giving up some control over how workers are managed. Moreover, its relationships with workers are now modified by the activities of another company, which, logically, is pursuing its own agenda. Therefore, companies need to understand that how they deal with intermediaries will affect the terms of their relationships with workers, and ultimately how they behave and perform. One key implication of this argument is that firms (clients) that are heavily invested in the use of externalized work arrangements need to incorporate their strategies for dealing with intermediaries into their companies' general HR strategies. All too often decisions are ad hoc and left to the discretion of individual hiring managers, which might have unintended consequences for the success of flexible staffing arrangements (see Bidwell, 2006).

We should also reconsider the symbiotic relationship between employment intermediaries and the legal institutions surrounding employment (at least in the United States). The basic structure of legislation on topics such as benefit provision and industrial relations is predicated on the fact that workers have a single employer. These assumptions have, in part, helped to spur the growth of triadic 
employment relationships, as client firms have looked to intermediaries to escape some of the more burdensome obligations attached to employment, such as the provision of benefits. The growth of these triadic arrangements, though, is undermining the policy goals enshrined in the legislation, as clients become increasingly able to pick and choose which obligations and for which workers they will retain responsibility for.

How best to revise the regulatory framework to recognize the reality of modern employment is a tricky question. On the one hand, modifying legal frameworks to make it simpler to identify client firms as co-employers would bring the legal system closer into line with the economic reality. On the other hand, industry responses to the Vizcaino ruling over Microsoft's temporary workers (e.g. Barley and Kunda, 2004) show how increasing employers' obligations to external workers can simply lead to more elaborate schemes to distance clients from workers, quite possibly to the detriment of both parties. Triadic employment arrangements are therefore likely to remain a difficult challenge to public policy for the foreseeable future.

Our qualitative findings also have implications for future research on contingent and intermediated employment. In particular, they argue for the need to examine these work arrangements as systems of ties, in which relationships interact in order to influence outcomes such as wages, task assignment, and employment security. We have offered some examples and patterns of these interactions, which could be used to develop specific hypotheses and test them using quantitative data sets (for a first effort to do this, see Bidwell and Fernandez-Mateo, 2006). In particular, a question that arises from our qualitative fieldwork is this: what are the circumstances under which specific ties will reinforce as opposed to balance each other? We need to extend this research using data from other occupations and types of intermediaries. In particular, we have argued that triadic employment arrangements are becoming more prevalent in the labor market, and that they include not just staffing agencies but also other actors such as outsourcing and even professional services companies. Studying how these interactions play out in other triadic settings should improve understanding of this increasingly important sector of the labor market.

The growth of triadic employment arrangements raises other questions for future research. For example, to what extent does the growth of external employment (employment through intermediaries) affect inequality within the labor market? We might suppose that 
intermediaries offer client firms the opportunity to cut back on their obligations to some of their most vulnerable workers, such as lowskilled employees, increasing the gaps between the most and least successful. On the other hand, we have seen how intermediaries offer workers new opportunities for action. It is conceivable that some disadvantaged workers may actually find that triadic arrangements allow them to overcome obstacles to their advancement in more traditional relationships. For example, arrangements of this type could work as a stepping stone to permanent employment for workers who are having trouble finding regular jobs. Either way, it is important to gain a deeper understanding of who wins and who loses in triadic employment relationships. William Bielby and Denise Bielby (1999) have made an early attempt to address this question in the context of the film industry, but much more work remains to be done.

A third area that needs to be investigated relates to the sustainability of triadic arrangements. The dynamics of reinforcing and balancing highlight a certain tension in triadic arrangements. Workers are managing important relationships with two separate organizations with interests that sometimes align and sometimes conflict. It is possible that, over time, these dynamics will lead workers to become more clearly identified with one or other employer, effectively breaking up the triad. Examining how and whether workers and firms are able to balance these tensions over time will help us to understand whether triadic employment will continue to be an adjunct to more traditional, dyadic relationships, or whether they will become a precursor to the widespread adoption of network forms of organization.

\section{References}

Abraham, K. G. (1990). Restructuring the employment relationship: the growth of market-mediated work arrangements. In K. G. Abraham and R. B. McKersie (eds.), New Developments in the Labor Market: Toward a New Institutional Paradigm (85-118). Cambridge, MA: MIT Press.

Abraham, K. G., and Taylor, S. K. (1996). Firms' use of outside contractors: theory and evidence. Journal of Labor Economics, 14, 394-434.

Ang, S., and Slaughter, S. A. (2001). Work outcomes and job design for contract versus permanent information systems professionals on software development teams. MIS Quarterly, 25(3), 321-50. 
Autor, D. H. (2001). Why do temporary help firms provide free general skills training? Quarterly Journal of Economics, 116(4), 1409-49.

(2003). Outsourcing at will: the contribution of unjust dismissal doctrine to the growth of employment outsourcing. Journal of Labor Economics, 23(1), 1-42.

Baker, G., Gibbs, M., and Holmstrom, B. (1994). The wage policy of a firm. Quarterly Journal of Economics, 109(4), 921-55.

Barley, S. R., and Kunda, G. (2004). Gurus, Hired Guns and Warm Bodies: Itinerant Experts in a Knowledge Economy. Princeton, NJ: Princeton University Press.

Baron, J. N., and Hannan, M.T. (1994). The impact of economics on contemporary sociology. Journal of Economic Literature, 32(3), 1111-46.

Bidwell, M. 2006. Problems deciding: how the make or buy decision leads to transaction misalignment. Unpublished manuscript. Singapore: INSEAD.

Bidwell, M., and Fernandez-Mateo, I. (2006). Brokerage in the long run: how does relationship duration affect the returns to brokerage? Unpublished manuscript. Singapore: INSEAD.

Bielby, W. T., and Bielby, D. D. (1999). Organizational mediation of projectbased labor markets: talent agencies and the careers of screenwriters. American Sociological Review, 64(1), 64-85.

Blau, P. M. (1964). Exchange and Power in Social Life. New York: Wiley.

Broschak, J. P., and Davis-Blake, A. (2006). Mixing standard work and nonstandard deals: the consequences of heterogeneity in employment arrangements. Academy of Management Journal, 49(2), 371-93.

Burt, R.S. (1992). Structural Holes: The Social Structure of Competition. Cambridge, MA: Harvard University Press.

Cappelli, P. (1995). Rethinking employment. British Journal of Industrial Relations, 33(4), 563-602.

(1999). The New Deal at Work: Managing the Market-Based Employment Relationship. Boston: Harvard Business School Press.

Cook, K. S., and Emerson, R. M. (1978). Power, equity and commitment in exchange networks. American Sociological Review, 43(5), 721-39.

Cook, K. S., and Whitmeyer, J. M. (1992). Two approaches to social structure: exchange theory and network analysis. Annual Review of Sociology, 18, 109-27.

Davidov, G. (2004). Joint employer status in triangular employment relationships. British Journal of Industrial Relations, 42(4), 727-46.

Davis-Blake, A., and Broschak, J. P. (2000). Speed bumps of stepping stones: the effects of labor market intermediaries on relational wealth. In C. Leana and D.M. Rousseau (eds.), Relational Wealth: A New 
Model for Employment in the 21st Century (91-115). Oxford: Oxford University Press.

Davis-Blake, A., and Uzzi, B. (1993). Determinants of employment externalization: a study of temporary workers and independent contractors. Administrative Science Quarterly, 38, 195-223.

Doeringer, P. B., and Piore, M.J. (1971). Internal Labor Markets and Manpower Analysis. Lexington, MA: D.C. Heath.

Emerson, R. M. (1962). Power-dependence relations. American Sociological Review, 27(1), 31-41.

(1972). Exchange theory, part II: exchange relations and networks. In J. Berger, M. Zelditch, and B. Anderson (eds.), Sociological Theories in Progress, vol. II (58-87). Boston: Houghton Mifflin.

(1976). Social exchange theory. Annual Review of Sociology, 2, 335-62.

Fernandez-Mateo, I. (2007). Who pays the price of brokerage? Transferring constraint through price setting in the staffing sector. American Sociological Review, 72(2), 291-317.

Finlay, W., and Coverdill, J.E. (2000). Risk, opportunism and structural holes: how headhunters manage clients and earn fees. Work and Occupations, 27(3), 377-405.

Gargiulo, M. (1993). Two-step leverage: managing constraint in organizational politics. Administrative Science Quarterly, 38(1), 1-19.

Glaser, B., and Strauss, A. (1967). The Discovery of Grounded Theory. Chicago: Aldine de Gruyter.

Gramm, C. L., and Schnell, J. F. (2001). The use of flexible staffing arrangements in core production jobs. Industrial and Labor Relations Review, 54(2), 245-58.

Houseman, S. N. (2001). Why employers use flexible staffing arrangements: evidence from an establishment survey. Industrial and Labor Relations Review, 55(1), 149-70.

Houseman, S. N., Kalleberg. A. L., and Erickcek, G. A. (2003). The role of temporary agency employment in tight labor markets. Industrial and Labor Relations Review, 57(1), 103-27.

Kalleberg, A. L., Reskin, B. F., and Hudson, K. (2000). Bad jobs in America: standard and non-standard employment relations and job quality in the United States. American Sociological Review, 65, 256-78.

Krackhardt, D. (1999). The ties that torture: Simmelian tie analysis in organizations. Research in the Sociology of Organizations, 16, 183-210.

Kunda, G., Barley, S. R., and Evans, J. (2002). Why do contractors contract? The experience of highly skilled technical professionals in a contingent labor market. Industrial and Labor Relations Review, 55(2), 234-61. 
Marsden, P. V. (1982). Brokerage behavior in restricted exchange networks. In P. V. Marsden and N. Lin (eds.), Social Structure and Network Analysis (201-18). Beverly Hills: Sage.

Miles, M. B., and Huberman, A. M. (1994). Qualitative Data Analysis (2nd edn.). Thousand Oaks, CA: Sage.

Monthly Labor Review (1998). The law at work. 121(10), 32-4.

Muhl, G. (2002). What is an employee? The answer depends on federal law. Monthly Labor Review, 125(1), 3-11.

Neumark, D., Polsky, D., \& Hansen, D. (1999). Has job stability declined yet? Evidence for the 1990s. Journal of Labor Economics, 17(4, 2), S29-S64.

Osterman, P. (1999). Securing Prosperity: How the American Labor Market has Changed and What to Do about It. Princeton, NJ: Princeton University Press.

Pfeffer, J., and Baron, J. (1988). Taking the workers back out: recent trends in the structuring of employment. Research in Organizational Behavior, 10, 257-303.

Storrie, D. (2002). Temporary Agency Work in the European Union. Dublin: European Foundation for the Improvement of Living and Working Conditions.

Van Dyne, L. and Ang, S. (1998). Organizational citizenship behavior of contingent workers in Singapore. Academy of Management Journal, 41(6), 692-703.

Wolff, K. H. (ed.) (1950). The Sociology of Georg Simmel. Glencoe, IL: Free Press. 